\title{
Reproductive response of a tropical mammal, the musk shrew (Suncus murinus), to photoperiod
}

\author{
Emilie F. Rissman*, R. J. Nelson†, J. L. Blank $\ddagger$ and F. H. Bronson \\ Institute of Reproductive Biology, Department of Zoology, University of Texas, Austin, TX 78712, \\ U.S.A.
}

\begin{abstract}
Summary. Musk shrews (Suncus murinus) were maintained for 8 weeks in long ( $16 \mathrm{~h}$ light: $8 \mathrm{~h}$ darkness) or short ( $8 \mathrm{~h}$ light: $16 \mathrm{~h}$ darkness) daylengths. Males housed in short daylengths had significantly lighter androgen-dependent sex accessory organs than did males kept in long daylengths. This same trend was noted in male sexual behaviour. However, the weights of the testes and epididymides and sperm numbers did not differ. Females housed in short daylengths had significantly lighter cervices and were less likely to demonstrate sex behaviour than animals kept in under long daylengths. Ovarian and uterine weights did not differ. These results suggest that the ability to respond to photoperiod can exist in tropical mammals, even if it is not used as a cue to time seasonal breeding.
\end{abstract}

\section{Introduction}

Tropical mammals often breed seasonally in relation to variation in rainfall and hence food availability (Sadleir, 1969; Bronson, 1985). Little information is available on the use of photoperiodic prediction in these animals. Obviously the potential for photoperiod to function as a predictive cue diminishes rapidly as the equator is approached since here seasonal changes in photoperiod are minimal or non-existent. Reliance upon this cue nevertheless could prove advantageous in the higher latitudes of the tropics. In these areas photoperiodic information could allow metabolic preparation for a breeding season, if the breeding season was predictably recurring.

The best way to establish a species' potential responsiveness to photoperiod is to subject it to variation in daylength in a controlled environment. This has been done repeatedly with temperatezone mammals, and many have proven responsive to this cue (Sadlier, 1969; Zucker et al., 1980). Only two tropical mammals, both lemurs from Madagascar, have been tested in this manner (Petter-Rousseaux, 1970; Van Horn, 1975). The reproductive systems of both species responded to photoperiod.

The object of the present experiment was to determine whether photoperiod could regulate the reproduction of a small tropical insectivore, the musk shrew (Suncus murinus). Musk shrews are widely distributed throughout the tropical Pacific and Asia. They are present in urban and rural environs and breed throughout the year (Harrison, 1955; Peterson, 1956; Barbehenn, 1962; Morita, 1964; Louch et al., 1966).

\footnotetext{
*Present address: Department of Psychology, Gilmer Hall, University of Virginia, Charlottesville, VA 22903, U.S.A. $\dagger$ Present address: Department of Psychology, The Johns Hopkins University, Baltimore, MD 21218, U.S.A. $\ddagger$ Present address: Department of Biological Sciences, Kent State University, Kent, Ohio 44242, U.S.A.
} 


\section{Materials and Methods}

The musk shrews used in these experiments were born and raised in our colony at the Univeristy of Texas. The original stock were trapped in the early 1960 s on the island of Guam at a latitude of $13^{\circ} \mathrm{N}$. The animal rooms were maintained on a $14 \mathrm{~h}$ light: $10 \mathrm{~h}$ darkness photoperiod (lights on at $07: 00 \mathrm{~h} \mathrm{CST}$ ) at a temperature of $23 \pm 1^{\circ} \mathrm{C}$. Food (a mixture of Purina cat chow and Beatrice complete mink diet) and water were provided ad libitum. In these experiments 21 male and 24 female weanlings, $18-20$ days of age, were isolated in individual cages $(32.5 \times 17.5 \times 12.5 \mathrm{~cm})$ and randomly assigned to reside in long $(16 \mathrm{~L}: 8 \mathrm{D})$ or short $(8 \mathrm{~L}: 16 \mathrm{D})$ daylengths for 8 weeks. The sexes were segregated by room.

At the end of the 8-week treatment each animal was tested for sexual activity. Behavioural tests were conducted between 08:00 and 12:00 h in arenas $(44 \times 23 \times 14 \mathrm{~cm})$. All animals were tested sexually with stimulus animals housed under normal colony conditions. Experimental males were tested with adult females $2448 \mathrm{~h}$ post partum, when receptivity is maximum (Rissman, 1987a). Females were tested for receptivity with proven stud males. Each musk shrew was given a maximum of two behaviour tests separated by $48 \mathrm{~h}$. Animals were tested a second time only if they failed to exhibit a complete sequence of sexual behaviour culminating in ejaculation by the male on their first behaviour test.

Males were killed 2 days after ejaculation to obtain meaningful sperm counts. At autopsy sperm counts from both testes were made following the procedures of Kirton et al. (1967). In addition, testes, epididymides, seminal vesicles and flank glands were rapidly removed, cleaned and weighed. Females were killed after their final behaviour test. Their uteri, ovaries and cervices were likewise removed, cleaned and weighed. The cervix is distinguishable from the vagina and appears as a band of white, rigid tissue located between the vagina and the uterine horns. Data were analysed by paired Student's $t$ tests. Organ weights were expressed as a proportion of body weight. Data on mating frequency were subjected to $\chi^{2}$ analysis.

\section{Results}

Exposure to short daylengths did not alter spermatogenesis in male musk shrews (Table 1). Average weights of the testes and epididymides were equivalent in long- and short-day exposed males, as were the numbers of spermatozoa in the testes. In contrast, weights of the androgensensitive flank glands and seminal vesicles were significantly suppressed in males reared in short daylengths $(P<0.001)$. This same tendency was apparent in the sexual behaviour of these males, but the difference was not significant $\left(\chi^{2}=3 \cdot 70\right)$. Body weight was significantly lower in males maintained in short daylengths $(P<0.05)$.

Analyses of organ weights of female musk shrews must be interpreted with caution. The hormonal regulation of these organs differs markedly from that of other mammals. The uterus, for

Table 1. Reproductive condition (mean \pm s.e.m. for 10-11 animals/group) of male musk shrews after 8 weeks of maintenance in short or long daylengths

\begin{tabular}{|c|c|c|c|}
\hline & $\begin{array}{l}\text { Short } \\
\text { days }\end{array}$ & $\begin{array}{l}\text { Long } \\
\text { days }\end{array}$ & Significance \\
\hline Body weight (g) & $32 \cdot 0 \pm 0.7$ & $36 \cdot 1 \pm 1 \cdot 5$ & $P<0.05$ \\
\hline $\begin{array}{l}\text { Wt of testes } \\
(\mathrm{mg} / 10 \mathrm{~g} \text { body } \mathrm{wt})\end{array}$ & $40 \cdot 8 \pm 1 \cdot 0$ & $40 \cdot 7 \pm 1 \cdot 4$ & N.S. \\
\hline $\begin{array}{l}\text { Wt of epididymides } \\
(\mathrm{mg} / 10 \mathrm{~g} \text { body } \mathrm{wt})\end{array}$ & $22 \cdot 1 \pm 2 \cdot 0$ & $19 \cdot 2 \pm 0 \cdot 8$ & N.S. \\
\hline $\begin{array}{l}\text { Testicular spermatozoa } \\
\left(\times 10^{-6}\right)\end{array}$ & $5 \cdot 4 \pm 0 \cdot 6$ & $5 \cdot 4 \pm 0 \cdot 6$ & N.S. \\
\hline $\begin{array}{l}\text { Wt of the flank glands } \\
\text { (mg/ } 10 \mathrm{~g} \text { body wt })\end{array}$ & $82 \cdot 2 \pm 2 \cdot 2$ & $96 \cdot 5 \pm 3 \cdot 5$ & $P<0.001$ \\
\hline $\begin{array}{l}\text { Wt of seminal vesicles } \\
\text { (mg/ } 10 \mathrm{~g} \text { body } \mathrm{wt})\end{array}$ & $17 \cdot 2 \pm 1 \cdot 3$ & $28 \cdot 7 \pm 1 \cdot 0$ & $P<0.001$ \\
\hline No. mating* & $3 / 10$ & $8 / 11$ & N.S. \\
\hline
\end{tabular}

*Number showing a full copulatory sequence in relation to the number tested. 
Table 2. Reproductive condition (mean \pm s.e.m. for 12 animals/group) of female musk shrews after 8 weeks of maintenance in short or long daylengths

\begin{tabular}{lccc}
\hline & Short days & Long days & Significance \\
\hline $\begin{array}{l}\text { Body weight }(\mathrm{g}) \\
\text { Wt of ovaries }\end{array}$ & $\begin{array}{r}19.5 \pm 0.5 \\
\quad 2.0 \pm 0.1\end{array}$ & $2.1 \pm 0.5$ & $P<0.01$ \\
$\quad(\mathrm{mg} / 10 \mathrm{~g}$ body wt) & & N.S. \\
$\begin{array}{c}\text { Wt of uterus } \\
\quad(\mathrm{mg} / 10 \mathrm{~g} \text { body wt) }\end{array}$ & $4.0 \pm 0.2$ & $4.5 \pm 0.3$ & N.S. \\
$\begin{array}{c}\text { Wt of cervix } \\
\text { (mg/ } 10 \mathrm{~g} \text { body wt) }\end{array}$ & $9 \cdot 1 \pm 1.2$ & $13.9 \pm 1.3$ & $P<0.02$ \\
No. mating* & $3 / 12$ & $11 / 12$ & $P<0.01$ \\
\hline
\end{tabular}

*Number showing a full copulatory sequence in relation to the number tested.

example, is insensitive to oestrogen (Dryden \& Anderson, 1977; Rissman \& Bronson, 1987). On the other hand, the cervix is sensitive to this steroid (E. F. Rissman, unpublished data) as is sexual behaviour (Rissman \& Bronson, 1987). Possibly analogous to our finding in males, then, is the fact that short-day exposure had no effect on ovarian or uterine weights. However, females housed in short daylengths did demonstrate significantly lower levels of sexual behaviour $\left(\chi^{2}=10.97\right.$; $P<0.01)$ as well as lighter cervix $(P<0.02)$ and body $(P<0.01)$ weights (Table 2$)$.

\section{Discussion}

The results suggest that steroidogenesis, but not gametogenesis, is sensitive to photoperiod in the musk shrew. Hormone-sensitive target tissues did respond to photoperiodic variation and sexual behaviour was also affected by daylength. Sexual behaviour in male musk shrews is androgendependent (Rissman, 1987b) while in females oestrogen or testosterone can reinstate sexual receptivity after ovariectomy (Rissman \& Bronson, 1987). However, some animals of both sexes maintained in short daylengths still matured sufficiently to mate when given the opportunity.

This evidence of reproductive response to photoperiod in the musk shrew is surprising. There is adequate seasonal variation in daylength to allow the use of photoperiod to cue reproduction on Guam (Elliott, 1976). Nevertheless one might ask why any small mammal would do so either on Guam or generally in the tropics except where rainfall patterns produce a greatly diminished food supply during some seasons. Small mammals usually face short life expectancies, and therefore one would expect some degree of opportunism to be a part of their reproductive strategies wherever they do not face harshly seasonal changes in food availability and climate. Photoperiodic regulation by itself is antagonistic to such flexibility.

There are two reasons why one should not expect this particular small mammal's reproduction to be responsive to variation in daylength. First, the musk shrew is an opportunistic commensal of man, infesting houses and commercial establishments wherever it can survive. In the northern temperate zone this niche is usually filled by rodent opportunists such as the house mouse and the Norway rat which are not sensitive to photoperiod (Davis, 1953; Bronson, 1979). Dependence on photoperiod to cue reproduction in a commensal habitat runs contrary to common sense since for these species changes in photoperiod are probably not predictive of the suitability of such a habitat for reproduction. Second, the musk shrew is known to breed continuously throughout the year wherever it has been studied, both in the tropics (Guam, Malaysia, and tropical India) and in southern Japan (Harrison, 1955; Barbehenn, 1962; Morita, 1964; Louch et al., 1966). Ecologically therefore, there is no reason why the musk shrew should be reproductively sensitive to photoperiod. 
A possible explanation for these results is that reproductive responsiveness to photoperiod in the musk shrew may be a selectively neutral relic from a place, a niche, and a time when this trait was advantageous for seasonal breeding. It exists now in a form that is normally overridden by other cueing systems which promote year round, uninterrupted breeding. This same type of system is found in Northern temperate-zone rodents in which inhibitory photoperiodic cues can be overridden by food availability (Berger et al., 1981). The musk shrew is thought to have originated in India where it spread widely throughout southeast Asia and the Pacific. The Guam population was founded about 1950, probably by immigrants from the tropical Philippines (Peterson, 1956). Our stock has been in the laboratory for over 25 years. In neither of these environments (the tropics or the laboratory) does it seem as though this trait would be selectively disadvantageous as long as it could be overridden in a way that would yield continuous breeding.

In summary, the present experiment does little to answer the larger question of how often tropical mammals use photoperiodic prediction to regulate their seasonal breeding. However, it does establish that this trait is present in at least one tropical mammal.

We thank Dr Michael Menaker for helpful comments on an earlier draft of this manuscript. This work was supported by NICHD Training Grant HD07264 and NSF grant PCM 8208289.

\section{References}

Barbehenn, K.R. (1962) Recent invasions of micronesia by small mammals. Micronesica $10,41-50$.

Berger, P.J., Negus, N.C., Sanders, E.H. \& Gardner, P.D. (1981) Chemical triggering of reproduction in Microtus montanus. Science, N.Y. 214, 69-70.

Bronson, F.H. (1979) The reproductive ecology of the house mouse. Quart. Rev. Biol. 54, 265-299.

Bronson, F.H. (1985) Mammalian reproduction: an ecological perspective. Biol. Reprod. 32, 1-26.

Davis, D.E. (1953) The characteristics of rat populations. Quart. Rev. Biol. 28, 373-401.

Dryden, G.L. \& Anderson, J.N. (1977) Ovarian hormones: lack of an effect on reproductive structures of female Asian musk shrews. Science, N.Y. 197, $782-784$.

Elliott, J.A. (1976) Circadian rhythms and photoperiodic time measurement in mammals. Fedn Proc. Fedn Am. Socs exp. Biol. 35, 2339-2346.

Harrison, J.L. (1955) Data on the reproduction of some Malayan mammals. Proc. zool. Soc. Lond. 125, 445-460.

Kirton, K.T., Desjardins, C. \& Hafs, H.D. (1967) Distribution of sperm in male rabbits after various ejaculation frequencies. Anat. Rec. 158, 287-292.

Louch, C.D., Ghosh, A.K. \& Bikash, C.P. (1966) Seasonal changes in weight and reproductive activity of Suncus murinus in West Bengal, India. J. Mammal. 47, 73-78.

Morita, S. (1964) Reproduction of the Riukiu musk shrew, Suncus murinus riukiuanus, Sci. Bull. Fac. Lib. Arts and Educ., Nagasaki Univ. 15, 17-40.
Peterson, G.D. (1956) Suncus murinus, a recent introduction to Guam. J. Mammal. 37, 278-279.

Petter-Rousseaux, A. (1970) Observations sur l'influence de la photoperiode sur l'activite sexuelle chez Microcebus murinus en captivite. Annls Biol. anim. Biochim. Biophys. 10, 203-288.

Rissman, E.F. (1987a) Social variables influence female sexual behavior in the musk shrew (Suncus murinus). J. comp. Psych. 101, 3-6.

Rissman, E.F. (1987b) Gonadal influences on sexual behavior in the male musk shrew (Suncus murinus). Horm. Behav. 21, 132-136.

Rissman, E.F. \& Bronson, F.H. (1987) Role of the ovary and adrenal gland in the sexual behavior of the musk shrew, Suncus murinus. Biol. Reprod. 36, 664-668.

Sadleir, R.M.F.S. (1969) The Ecology of Reproduction in Wild and Domestic Mammals. Methuen and Co., London.

Van Horn, R.N. (1975) Primitive breeding season: photoperiodic regulation in captive Lemur catta. Folia Primatol. 24, 203-220.

Zucker, I., Johnston, P.G. \& Frost, D. (1980) Comparative, physiological and biochronometric analysis of rodent seasonal reproductive cycles. Prog. Reprod. Biol. 5, 102-133. 